\title{
SARS-CoV-2 infection and thrombotic complications: a narrative review
}

\author{
Iraklis C. Moschonas ${ }^{1} \cdot$ Alexandros D. Tselepis $^{1}$
}

Accepted: 17 December 2020 / Published online: 15 January 2021

○) Springer Science+Business Media, LLC, part of Springer Nature 2021

\begin{abstract}
The current, global situation regarding the severe acute respiratory syndrome coronavirus-2 (SARS-CoV-2) pandemic and its potentially devastating clinical manifestations, i.e. coronavirus disease 2019 (COVID-19), took the world by storm, as millions of people have been infected worldwide and more than 1,600,000 patients have succumbed. Infection induced by various respiratory viruses may lead to thrombotic complications. Infection-elicited thrombosis may involve a repertoire of distinct, yet interconnected pathophysiological mechanisms, implicating a hyperinflammatory response, platelet activation and triggering of the coagulation cascade. In the present review, we present current knowledge on the pathophysiological mechanisms that may underlie thrombotic complications in SARS-CoV-2 infection. Furthermore, we provide clinical data regarding the incidence rate of thrombotic events in several viral respiratory infections that cause acute respiratory distress syndrome, including SARS-CoV-2 infection and finally we summarize current recommendations concerning thromboprophylaxis and antithrombotic therapy in patients with thrombotic complications related to SARS-CoV-2 infection.
\end{abstract}

Keywords Acute respiratory distress syndrome $\cdot$ Antithrombotic therapy $\cdot$ COVID-19 Endothelium · Inflammation · Respiratory viruses $\cdot$ SARS-CoV-2 $\cdot$ Thrombosis $\cdot$ Venous thromboembolism

\section{Highlights}

- SARS-CoV-2 infection is associated with an increased risk of arterial and venous thrombotic events.

- The pathophysiological mechanisms underlying thrombotic events in SARS-CoV-2 infection include platelet activation, triggering of the coagulation cascade, the formation of neutrophil extracellular traps (NETs) and "cytokine storm" syndromes.

- Antithrombotics, such as low-molecular-weight heparin or unfractionated heparin, are used for thromboprophylaxis or for the treatment of thrombotic events related to SARS-CoV-2 infection.

- More studies are required to fully elucidate the pathophysiological mechanisms responsible for thrombotic events in COVID-19 patients, as well as to increase the

Alexandros D. Tselepis

atselep@uoi.gr

1 Atherothrombosis Research Centre/Laboratory of Biochemistry, Department of Chemistry, University of Ioannina, 45110 Ioannina, Greece efficacy of the current antithrombotic treatment strategies. This will help reduce even more the incidence of such events.

\section{Introduction}

As of December 2020, approximately 70,000,000 people have been infected by the severe acute respiratory syndrome coronavirus-2 (SARS-CoV-2), whereas more than 1,600,000 have died from the coronavirus disease 2019 (COVID-19), according to the World Health Organization (https://www. who.int/emergencies/diseases/novel-coronavirus-2019, accessed on December 16, 2020).

SARS-CoV-2 infection occurs via its binding to the angiotensin-converting enzyme 2 (ACE2), expressed on various cell types, including type II pneumocytes, as well as macrophages and endothelial cells (ECs) [1]. Two proteins required for the entrance of SARS-CoV-2 into the target cells are the transmembrane protease serine 2 (TMPRSS2) and the main protein (Mpro) [2-5]. SARS-CoV-2 binding to ACE2 and TMPRSS2 occurs through the spike (S) protein, especially through the $\mathrm{N}$-terminal domain of its $\mathrm{S} 1$ subunit 
[2]. Therefore, co-expression of ACE2 and TMPRSS2 on the target cells is a pre-requisite for cell infection. Infected cells undergo pyroptosis, a highly inflammatory type of cell death, which results in the release of damage-associated molecular patterns (DAMPs), inducing and perpetuating a hyperinflammatory response.

COVID-19 patients may exhibit coagulation abnormalities, resulting in a hypercoagulable state, and in an increased rate of thrombotic and thromboembolic events [6]. Indeed, in hospitalized COVID-19 patients, the rate of thrombotic events in intensive care units (ICU) is approximately $29.4 \%$, whereas in non-ICU is $11.5 \%$ [7]. In this review, we provide insights on the pathophysiological mechanisms that may underlie coagulopathy and thrombotic complications in respiratory viral infections that induce acute respiratory distress syndrome (ARDS), primarily focusing on SARSCoV-2 infection. The clinical data on the incidence rate of thrombotic events in several respiratory viral infections that cause ARDS is also presented. Finally, we summarize current recommendations concerning thromboprophylaxis and antithrombotic therapy in COVID-19 patients.

We independently searched the Medline bibliographic database. Any article considered potentially relevant by authors, was retrieved for full review. The search strategy involved the use of the following keywords: "Acute Respiratory Distress Syndrome", "Antithrombotic therapy", "COVID-19", "Endothelium", "Inflammation", "Respiratory viruses", "SARS-CoV-2", "Thrombosis", "Venous Thromboembolism", in any field (title, abstract and/or the main body) of papers. Exclusion criteria were articles written in any language apart from English.

\section{Possible pathophysiological mechanisms underlying hypercoagulability and thrombotic complications in respiratory viral infections}

Several respiratory viral infections induce hypercoagulability and are associated with increased risk of arterial and venous thrombosis. Notably, an association of viral acute respiratory infections, especially influenza, and acute myocardial infarction has been observed, whereas the incidence of venous thromboembolic events following influenza infection has also been reported [8,9]. However, infection-related thrombotic events may occur in patients with an atherosclerotic background or undiagnosed cardiovascular disease [10]. In support of the association between respiratory viral infections and thrombosis are the results of a meta-analysis of randomized clinical trials showing that influenza vaccination is associated with a significant reduction in the rate of cardiovascular events, especially in high-risk patients who have experienced an acute coronary syndrome [11].
Accumulated evidence suggests a variety of possible cellular and molecular mechanisms that are accountable for the observed thrombotic complications. Among them, an overwhelming inflammatory response, in conjunction with platelet activation and a pro-coagulant phenotype seems to play a major role in the manifestation of respiratory viral infection-related thrombotic complications.

Viral respiratory infections are associated with the activation of platelets and the coagulation cascade [12, 13], thus increasing the incidence of thrombotic events. Platelets express on their surface several receptors, such as toll-like receptors (TLRs) and C-type lectin receptors, that recognize viruses as well as viral components, and commit platelets to respond to them [14]. A small study involving patients suffering from upper respiratory tract viral infections, reported higher platelet reactivity in these patients, expressed as adenosine diphosphate (ADP)-induced aggregation and P-selectin membrane expression, compared with platelets from healthy individuals [12]. Platelet P-selectin significantly contributes to the pro-thrombotic and pro-inflammatory platelet activities, through binding to its glycoprotein ligand-1 (PSGL-1), expressed on leukocytes, thus promoting monocyte and neutrophil activation [15]. In addition to P-selectin, activated platelets express and release a plethora of pro-inflammatory and pro-thrombotic mediators, such as CD40L, ADP, arachidonic acid (AA), von Willebrand factor (vWF) and chemokines, which mediate platelet interaction with leukocytes and ECs, thus inducing activation of these cells [15]. In addition to platelet activation, viral respiratory infections induce membrane expression of tissue factor (TF) by monocytes and ECs, through activation of nuclear factor kappa $\mathrm{B}$, thus initiating the coagulation cascade, whereas they also induce the release of various pro-inflammatory cytokines, such as interleukin (IL)-1 $\beta$ and -8 [13].

\section{SARS-CoV-2 infection and risk of thrombosis}

\section{SARS-CoV-2 infection and cellular components involved in thrombosis}

\section{SARS-CoV-2 infection and endothelial cell activation}

Except for the lung epithelium, SARS-CoV-2 can also infect cells of other tissues, such as the vascular endothelium, heart and intestine, since ACE2 is expressed in these tissues too $[16,17]$. Indeed, evidence suggests that blood vessel organoids contain RNA of the virus after in vitro SARS-CoV-2 infection [18], whereas ECs of the aforementioned tissues, obtained from SARS-CoV-2-infected patients, contain the virus, and histological samples of COVID-19 patients have revealed EC inflammation and death [19]. The abundant 
expression of ACE2 receptors on ECs enhances their vulnerability to SARS-CoV-2 binding, membrane fusion and cell entry, thus inducing endothelial dysfunction and endotheliitis. Furthermore, SARS-CoV-2-infected patients exhibit increased concentration of pro-inflammatory factors, including IL-1 $\beta$, IL-6, monocyte chemoattractant protein-1 (MCP-1) and interferon $\gamma$, which adversely affect endothelial integrity and functionality and lead to the endothelial expression of molecules such as vWF, intercellular adhesion molecule-1 (ICAM-1), P- and E-selectin [20, 21], which in turn results in platelet and leukocyte attraction and activation $[22,23]$, as well as in complement activation. Moreover, the hypoxia that these patients suffer, leads to overexpression of TF via hypoxia-inducing factors, which can trigger the coagulation cascade [24]. All the above data advocate to the display of a pro-coagulant and pro-thrombotic phenotype, related to the endothelial dysfunction and endotheliitis caused by SARS-CoV-2.

\section{SARS-CoV-2 infection and platelet activation}

Thrombocytopenia is a characteristic feature in patients exhibiting severe COVID-19. Indeed, the results of a metaanalysis demonstrated that thrombocytopenia is associated with a fivefold increased risk of severe disease, albeit it is not a common finding in non-severe COVID-19 [25]. Importantly, platelets express ACE2, rendering them a target cell to SARS-CoV-2 infection and leading to their activation [26]. SARS-CoV-2-activated platelets secrete a repertoire of chemokines, e.g. platelet factor 4, regulated on activation, normal $\mathrm{T}$ expressed and secreted (RANTES), CCL3 and -7 and CXCL1, -5 and -7 , which potentiate the recruitment of leukocytes, granting platelets a pro-inflammatory phenotype in the setting of SARS-CoV-2 infection [25]. Furthermore, activated platelets secrete inorganic polyphosphate, which activates the contact pathway, as well as high-mobility group box-1, which potentiates the recruitment of monocytes, the membrane expression of monocyte TF and the shedding of monocyte-derived TF-bearing microparticles, that in turn leads to activation of the coagulation cascade [25]. Moreover, platelets play a role in modulating the adaptive immunity, since they participate in the recruitment and proliferation of T-cells [27, 28], as well as they increase the production of immunoglobulins from B-cells [29].

\section{SARS-CoV-2 infection and neutrophil extracellular traps}

Activated neutrophils can form neutrophil extracellular traps (NETs), a web-like material structured from DNA and a multitude of proteins [30]. The process of NET formation is termed "NETosis". NETs display pro-inflammatory properties, since they are produced and participate in the pathogenesis of sterile and non-sterile inflammatory conditions, including atherogenesis, arterial and venous thrombosis [31]. Although NETosis is a beneficial mechanism of innate immune response when properly controlled, persistent NETosis can be detrimental to the host, since NETs bear multiple proteases that can be harmful to the endothelium and other tissues [32, 33]. NETs are also generated in response to viruses, such as influenza [34]. In this regard, several studies reported that NETs are also employed in response to SARS-CoV-2 [35-38]. Indeed, COVID19 is associated with neutrophil infiltration to the lungs, lung injury, microthrombosis in the lung vasculature and increased markers of NETosis, such as myeloperoxidaseassociated DNA and citrullinated histone $\mathrm{H} 3$, in the serum of COVID-19 patients [35-38]. NETs can be formed directly in the presence of DAMPs or pathogen-associated molecular patterns, or in response to cytokines, such as IL-8 [30]. Additionally, NETs can be formed indirectly by platelets activated either via classic platelet agonists (e.g. thrombin, ADP, AA) [39-41] or via other receptors (e.g. TLR4) [42]. Once formed, NETs express pro-coagulant and pro-thrombotic effects inducing platelet activation [40, 43, 44], as well as through the accumulation of pro-thrombotic molecules such as fibrin, vWF [43] and TF on their structure [40]. NETs also activate the contact pathway [25] and promote the gene expression of coagulation factors [45]. Hence, aberrant NETosis has adverse consequences to the host and may contribute to thrombotic complications in COVID-19 patients.

\section{SARS-CoV-2 infection and non-cellular components involved in thrombosis}

\section{SARS-CoV-2 infection and "cytokine storm" syndromes}

Another factor contributing to thrombotic complications in SARS-CoV-2 and other respiratory viral infections are the "cytokine storm" syndromes, characterized by elevated concentrations of various cytokines, including IL- $1 \beta,-2,-6$, -7 , granulocyte colony-stimulating factor, MCP-1, tumor necrosis factor- $\alpha$ and ferritin [46-48]. Cytokine storm syndromes may activate the coagulation cascade and on the other hand, coagulation factors can act as triggers of the cytokine storm [46-48]. Moreover, NETs can aggravate the overproduction of cytokines, as well as the pro-coagulant and pro-thrombotic status [37, 38]. Ultimately, the overproduction of cytokines, as well as the development of thrombi, are crucial for multi-organ injury [47, 48], such as lung, cardiac and hepatic injury, and eventual failure, which may lead to death. 


\section{SARS-CoV-2 infection and complement activation}

The nucleocapsid $(\mathrm{N})$ protein of SARS-CoV-2 binds to the mannose-binding lectin-associated serine protease (MASP)2 , which is expressed on the microvasculature, thus leading to complement activation [25]. This activation potentiates the aforementioned mechanisms through the overexpression of endothelial and monocyte TF, as well as through increasing platelet activation. It also enhances endothelial inflammation, thus further increasing the production of pro-inflammatory cytokines from ECs, such as IL-1, -6, -8, RANTES and MCP-1. Activation of the complement component $\mathrm{C} 3$ is associated with activation of the contact pathway and may play an important role in disease pathogenesis and exacerbation [49]. Consistent with the above results is the observation that deletion of $\mathrm{C} 3$ in mice infected with mouse-adapted severe acute respiratory syndrome coronavirus-1 (SARS-CoV-1) is associated with reduced neutrophil and monocyte numbers, as well as reduced cytokine levels in these animals [49], suggesting the participation of C3 in the inflammatory response.

\section{SARS-CoV-2 infection and thrombin generation}

Activation of the contact pathway, as well as the increased expression of $\mathrm{TF}$, through the above described mechanisms, lead to enhanced thrombin generation in COVID-19 patients.

Thrombin is an important protease in thrombosis, since it cleaves fibrinogen to produce fibrin and also activates platelets through protease-activated receptor (PAR)-1 and -4 [50]. These receptors are expressed in all tissues and mediate a variety of cellular effects, including endothelial and leukocyte activation, thus promoting a pro-inflammatory phenotype. In this regard, thrombin-induced activation of ECs through PAR-1 upregulates platelet-activating factor, MCP-1, IL-6 and -8, as well as P- and E-selectin and ICAM-1, which enhance the recruitment of leukocytes to the endothelium and further leukocyte activation. Ultimately, the activation of platelets, ECs and leukocytes leads to thrombin generation via a positive feedback loop, which plays an important role in the thrombotic clinical manifestations observed in severe COVID-19 patients, such as ischemic stroke, pulmonary embolism (PE) and deep vein thrombosis (DVT) [25].

\section{SARS-CoV-2 infection and antiphospholipid syndrome}

Another possible factor contributing to the thrombotic complications observed in respiratory viral infections, such as those caused by influenza A/H1N1 and SARS-CoV-2, is antiphospholipid syndrome (APS) [51]. In this regard, antiphospholipid antibodies have been identified in COVID19 patients [52]. Antiphospholipid antibodies in COVID-19 patients are predominantly directed against beta-2-glycoprotein I, but to a different epitope compared to the one targeted by antiphospholipid antibodies of individuals with established, non-COVID-19-related APS [53].

In COVID-19-related APS, increased concentrations of antiphospholipid antibodies have been associated with increased platelet numbers, worse respiratory disease manifestation, as well as nephrological abnormalities [54]. Importantly, increased levels of antiphospholipid antibodies in COVID-19 patients have been also associated with increased NETosis [54]. Moreover, IgG antiphospholipid antibody fractions from COVID-19 patients induced NETosis in neutrophils from control individuals, a finding also observed in patients with non-COVID-19-related APS, whereas administration of these fractions to mice resulted in venous thrombosis [54]. Indeed, previous reports suggested that NETs are linked to the pathogenesis of APS [55]. However, other researchers suggested that antiphospholipid antibodies are not frequent in COVID-19 patients and they are not responsible for the occurrence of major thrombotic events in these subjects [53].

A comprehensive illustration of the above described mechanisms of thrombotic complications during respiratory viral infections are presented in Fig. 1.

\section{Main clinical data involving thrombotic complications in respiratory viral infections}

The thrombotic complications reported in COVID-19 patients [56-59] are a common feature of respiratory viral infections, like those caused by influenza viruses [9, 60-62] and other betacoronaviruses, including SARS-CoV-1 and Middle Eastern respiratory syndrome coronavirus (MERS$\mathrm{CoV}$ ) [63]. The clinical data of several studies, involving thrombotic complications in various respiratory viral infections, is summarized in Table 1.

Results from a recent study involving 183 SARS-CoV2-infected patients, demonstrated that 21 (about 11.5\%) deceased, whereas among the non-survivors 15 (about 71.4\%) developed overt disseminated intravascular coagulation (DIC) [56]. In another study involving 81 COVID-19 severe cases admitted to the ICU, 20 (about 25.0\%) developed venous thromboembolism (VTE), of which 8 (40.0\%) did not survive [57]. Similar results were reported in 184 COVID-19 patients who were admitted to the ICU and were receiving thromboprophylaxis. The cumulative incidence of the composite outcome of VTE or arterial thrombotic events in these patients was 31\% (27\% VTE and 3.7\% arterial thrombosis). Among them, PE was the predominant thrombotic event ( 25 cases; about $80.6 \%$ ), whereas all arterial thrombosis cases were ischemic strokes [58]. In another report involving 25 COVID-19 patients, 7 (28\%) developed 
PE [59]. A multi-national meta-analysis of 17,799 hospitalized COVID-19 patients from 11 countries demonstrated that the total risk of stroke is $0.5 \%$, with a pooled risk of $0.9 \%$, whereas the need for mechanical ventilation support and the history of ischemic heart disease of the patients are independent prognostic factors of stroke [64]. Finally, in a more recent meta-analysis, it was demonstrated that major thromboembolic events, and especially PE, were particularly evident in COVID-19 patients admitted to the ICU [65].

Regarding influenza infection, it was reported that, among 119 hospitalized patients with H1N1 influenza A, 7 (about $5.9 \%)$ experienced a thrombotic event [60]. In another report, which involved 11,208 patients who suffered an acute myocardial infarction, 3927 (about 35.0\%) had an acute respiratory infection, including influenza [61]. Individuals with at least one indicator of influenza were more likely to develop myocardial infarction compared to those without any influenza indicators $(p=0.012)$, suggesting that influenza may constitute a stronger trigger for myocardial infarction than other respiratory infections [61]. Furthermore, it was documented that, among 252 hospitalized patients with confirmed H1N1 influenza A infection, 20 (about 7.9\%) became critically ill and required admission to the ICU. Among them, 5 (25.0\%) experienced a thrombotic event [9]. A more recent study reported that, among 36 patients

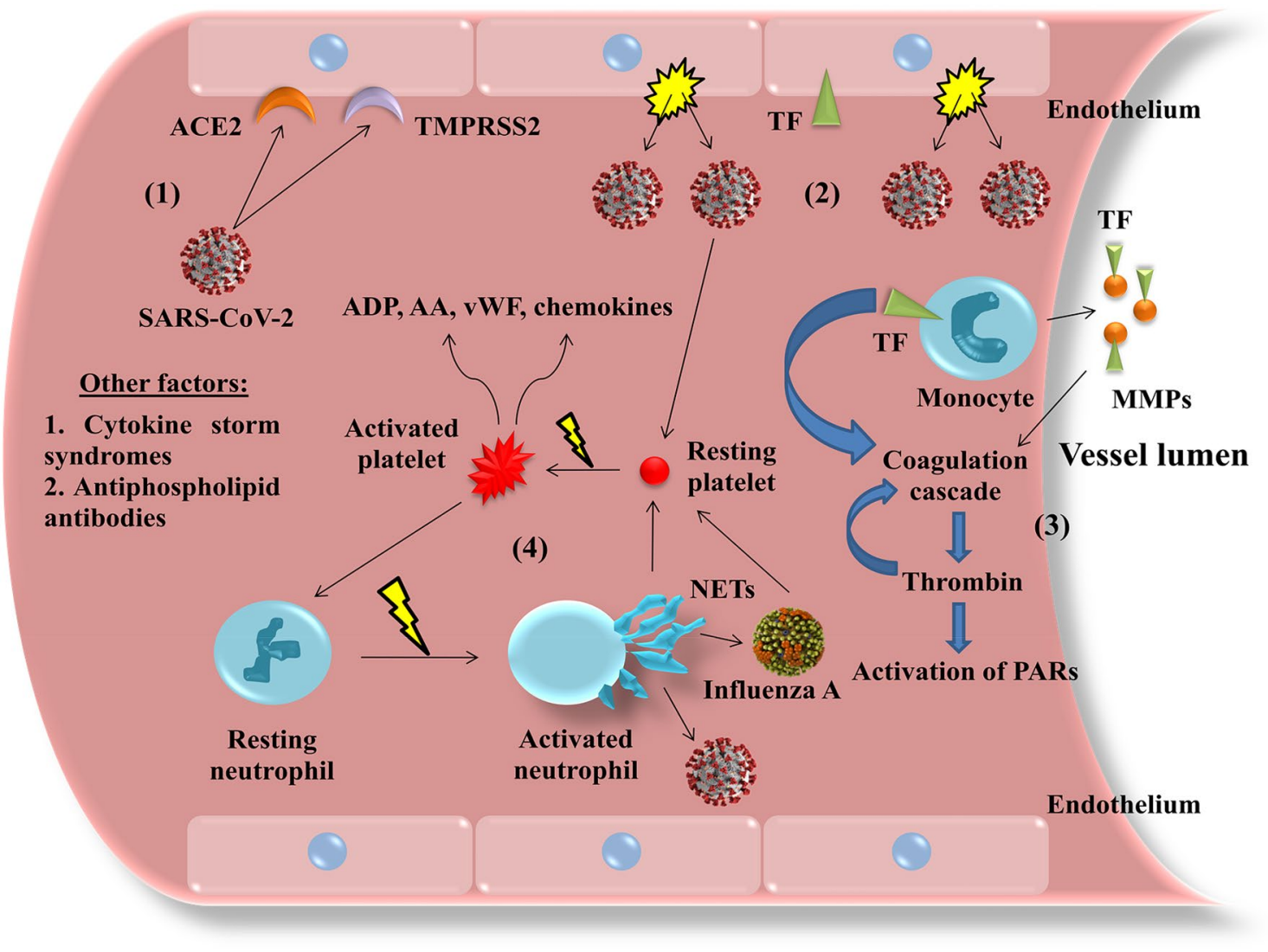

Fig. 1 Possible pathophysiological mechanisms implicated in thrombotic complications during respiratory viral infections. The presence of viruses, such as severe acute respiratory syndrome coronavirus-2 (SARS-CoV-2) and influenza A, triggers a series of cellular and molecular events that may be accountable for thrombotic complications in such infections. For example, SARS-CoV-2 enters endothelial cells via simultaneous binding to angiotensin-converting enzyme 2 (ACE2) and transmembrane protease serine 2 (TMPRSS2) (1), causing widespread endothelial disruption (2). Moreover, respiratory viral infections induce the membrane expression of tissue factor (TF) by endothelial cells, monocytes and monocyte-derived microparticles (MMPs), thus initiating the coagulation cascade which culminates in thrombin generation, which activates protease-activated receptors (PARs) and enhances the coagulation cascade in a positive feedback loop (3). Thrombin and other platelet agonists (e.g. adenosine diphosphate [ADP] and arachidonic acid [AA]), as well as viruses directly, activate platelets to express on their surface and release a plethora of pro-inflammatory and pro-thrombotic mediators, e.g. P-selectin and CD40L (not shown), more ADP and AA, von Willebrand factor (vWF) and various chemokines, which in turn activate endothelial cells and leukocytes. Notably, activated neutrophils form neutrophil extracellular traps (NETs), which arrest viruses but also bear prothrombotic properties, for example by activating more platelets in a vicious cycle (4). Other factors that contribute to the manifestation of a pro-thrombotic phenotype are the existence of cytokine storm syndromes (i.e. an overwhelming rise of cytokine levels, such as interleukins and other pro-inflammatory molecules) and possibly antiphospholipid antibodies, in a virus-related antiphospholipid syndrome 
admitted to the hospital with H1N1 influenza A infection, 16 (about 44.4\%) developed VTE [62].

Concerning SARS-CoV-1-infected patients, a study reported that, among 138 individuals, $44.8 \%$ had thrombocytopenia [66]. Another study demonstrated small vein thrombosis in 3 autopsied patients with SARS-CoV-1 [67]. Similarly, the presence of fibrin thrombi was reported in 1 among 6 autopsied SARS-CoV-1 patients [68]. In another study, the existence of hematologic abnormalities, including thrombocytopenia, at a rate of up to $45 \%$ in adults and $50 \%$ in children with SARS-CoV-1, was reported [69]. A retrospective analysis demonstrated that, among 157 SARSCoV-1-infected patients, 87 (about 55.4\%) developed thrombocytopenia, whereas 4 patients (about $2.5 \%$ ) developed DIC [70]. Finally, in another study, the incidence of large artery ischemic stroke in 5 out of 206 SARS-CoV-1-infected patients (about 2.4\%), was demonstrated [71].

Similarly to the above data, thrombotic vascular events have been also reported in MERS-CoV-infected patients. According to previously published results, thrombocytopenia was evident in 17 of 47 individuals (about 36.2\%) with confirmed MERS-CoV infection [72], whereas in another study thrombocytopenia was more pronounced in MERSCoV-infected patients (about $57.1 \%$, i.e. in 4 out of 7 individuals) [73]. Other investigators reported a case of MERSCoV-associated fatality which had presented DIC [74], whereas in another study, DIC was evident in 1 among 2 cases of MERS-CoV-related neurologic complications [75]. Finally, in a review article it was reported that the mortality rate among MERS-CoV-infected patients was about $30 \%$, whereas the corresponding rate in SARS-CoV-1-infected patients was $9.6 \%$ [76]. Importantly, DIC was one of the major complications in MERS-CoV-infected patients [76]. Due to the heterogeneous rates of thrombotic events in the above studies, it is difficult to draw a definite conclusion as to whether the prevalence of SARS-CoV-2-induced coagulopathy and thrombotic complications is greater, or not, than those related to other respiratory viral infections.

\section{Thromboprophylaxis and anticoagulant therapy in thrombotic complications related to respiratory viral infections}

The use of antithrombotics as thromboprophylaxis or to treat thrombotic events is a common practice in patients with respiratory viral infections. Notably, in influenza A/ H1N1-infected patients, even empirical anticoagulation therapy using heparin reduced the incidence of thromboembolic events in critically-ill subjects, without increasing the bleeding risk [62]. Moreover, in 184 severe COVID-19 patients the cumulative incidence of the composite outcome
Table 1 Main clinical data involving thrombotic complications in various viral infections

\begin{tabular}{|c|c|c|c|}
\hline Viral infection & Thrombotic complication(s) & Prevalence (patient numbers and rates) & References \\
\hline \multirow[t]{8}{*}{ SARS-CoV-2 } & Overt DIC & 21 of $183(11.5 \%)$ & {$[56]$} \\
\hline & VTE & 20 of $81(25.0 \%)$ & {$[57]$} \\
\hline & VTE or AT & 31 of $184(31 \% *)$ & {$[58]$} \\
\hline & $\mathrm{PE}$ & 7 of $25(28 \%)$ & {$[59]$} \\
\hline & VTE & 16 of $71(22.5 \%)$ & [77] \\
\hline & PE & 7 of $71(9.9 \%)$ & \\
\hline & VTE & 18 of $26(69.2 \%)$ & {$[78]$} \\
\hline & SIC & 97 of $449(21.6 \%)$ & [79] \\
\hline \multirow[t]{4}{*}{ Influenza A } & VTE or AT & 7 of $119(5.9 \%)$ & {$[60]$} \\
\hline & MI & 3927 of $11,208(35.0 \%)^{* *}$ & {$[61]$} \\
\hline & Thrombotic events & 5 of $252(2.0 \%)$ & [9] \\
\hline & VTE & 16 of $36(44.4 \%)$ & {$[62]$} \\
\hline \multirow[t]{4}{*}{ SARS-CoV-1 } & Small vein thrombosis & 3 autopsies & {$[67]$} \\
\hline & Presence of thrombi & 1 of 6 autopsies (17.0\%) & {$[68]$} \\
\hline & DIC & 4 of $157(2.5 \%)$ & [70] \\
\hline & Ischemic stroke & 5 of $206(2.4 \%)$ & [71] \\
\hline \multirow[t]{2}{*}{ MERS-CoV } & DIC & 1 autopsy & [74] \\
\hline & DIC & $\begin{array}{l}1 \text { of } 2 \text { patients with neurologic complica- } \\
\text { tions }(50 \%)\end{array}$ & [75] \\
\hline
\end{tabular}




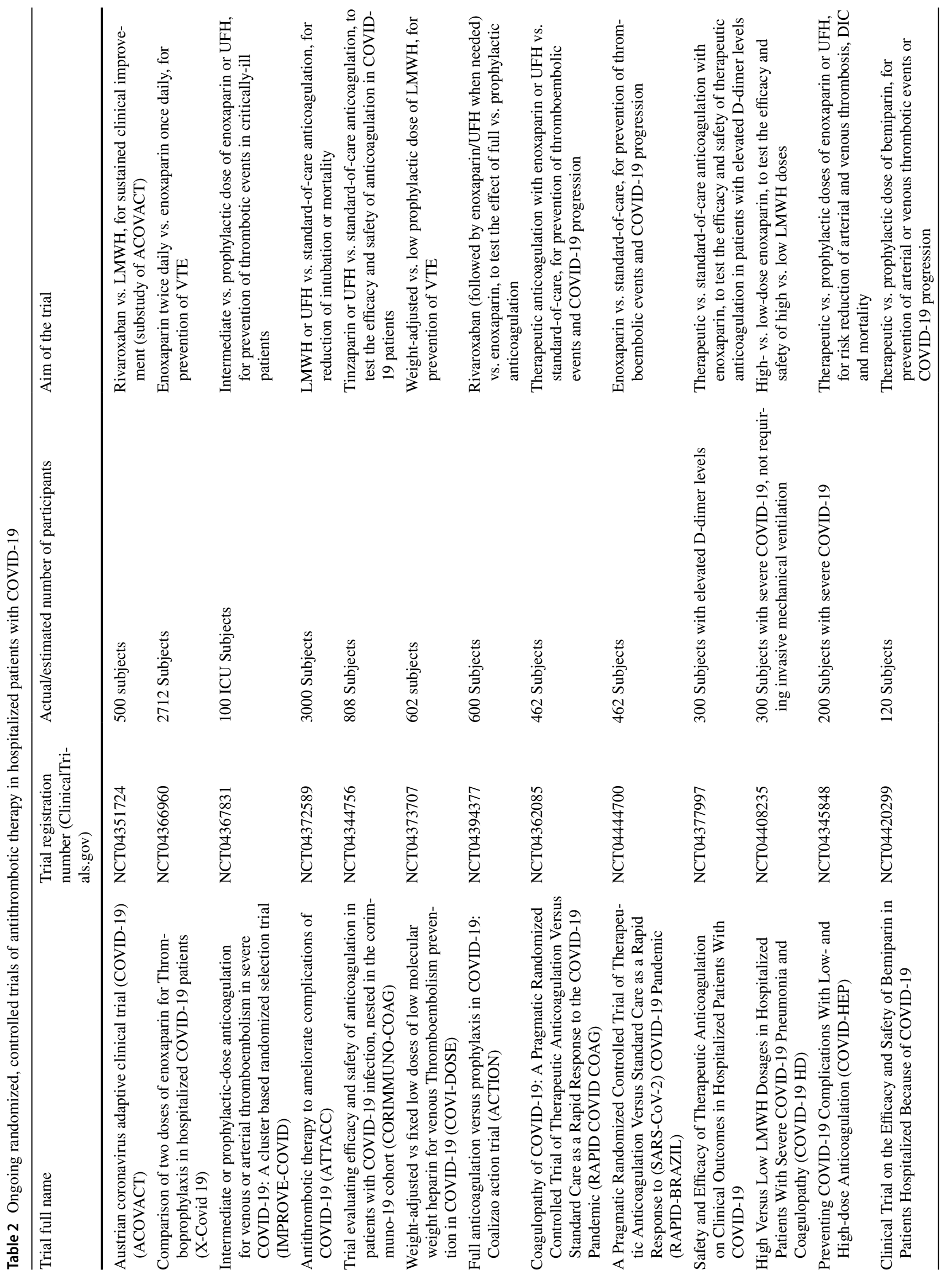




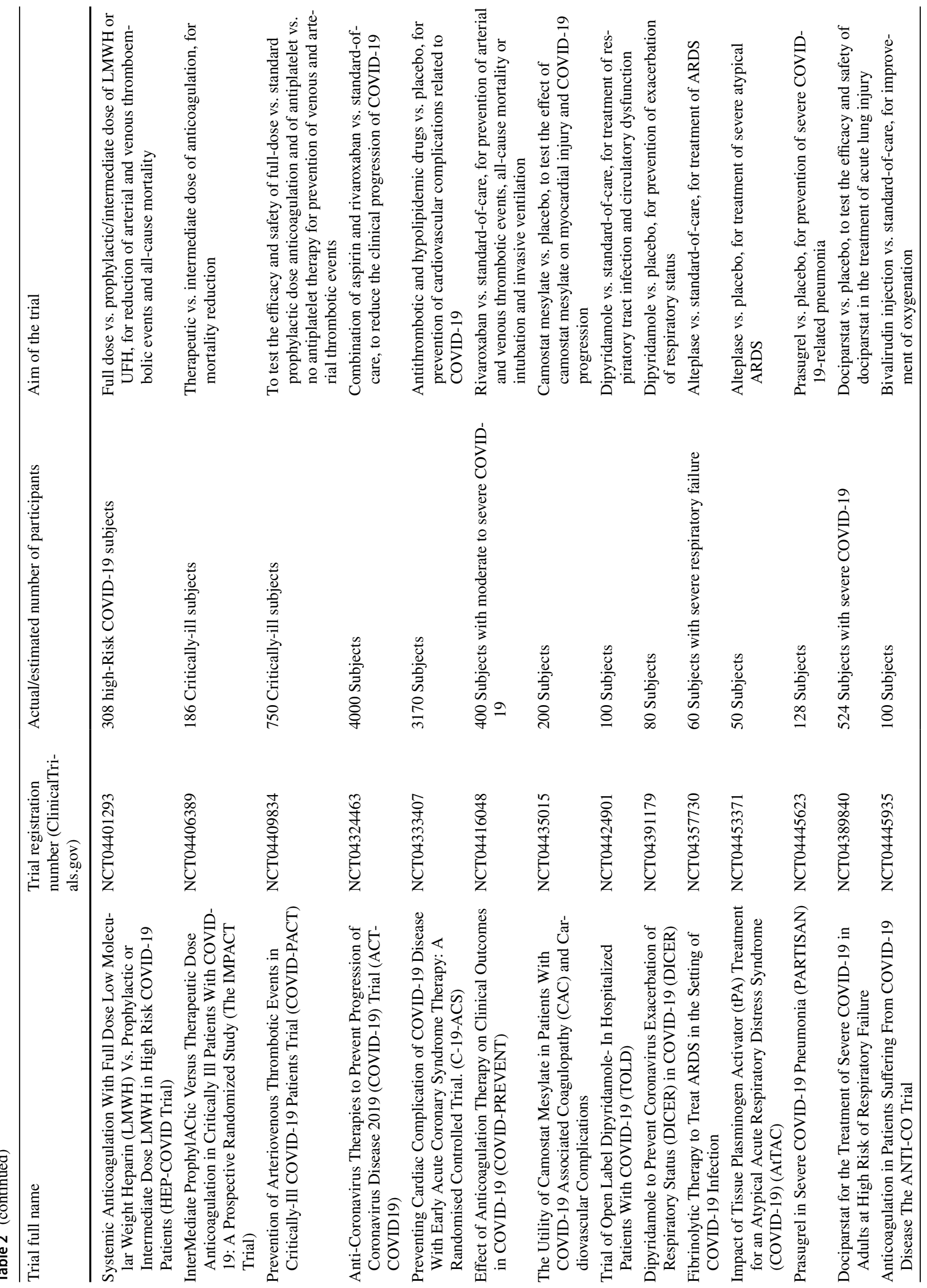


of venous or arterial thrombosis was $31 \%$, despite rigorous thromboprophylaxis [58]. This suggests that high prophylactic doses should be administered to such patients, in spite of the absence of relevant recommendations [58]. Similarly, in another study involving 71 COVID-19 patients under adequate thromboprophylaxis, who were not admitted to the ICU, a VTE incidence of about $22.5 \%$ was reported [77]. Authors concluded that heparin thromboprophylaxis should be aggressive and under the guidance of D-dimer levels, which may have a predictive value for VTE, with a cut-off value of $1.0 \mu \mathrm{g} / \mathrm{mL}$ [77]. In accordance with the above results, an additional study reported that COVID-19 patients receiving prophylactic anticoagulation had significantly higher rates of VTE compared to those receiving therapeutic anticoagulation with either low-molecular-weight heparin (LMWH) or unfractionated heparin $(100 \%$ vs. $56 \%$ respectively, $p=0.03$ ) [78]. Finally, other investigators found that administration of unfractionated heparin or LMWH improves the clinical outcome of COVID-19-associated thrombotic complications [59, 79].

In light of this data, the International Society of Thrombosis and Haemostasis (ISTH) has recommended the use of prophylactic doses of LMWH in all hospitalized COVID-19 patients (whether they have severe disease or not), in the absence of any contraindications [80]. LMWH should also prevent VTE incidence in critically-ill patients [80]. Moreover, the anti-inflammatory properties of LMWH would probably benefit patients from cytokine storm syndromes [80]. Other guidelines suggest thromboprophylaxis with the use of standard dose of unfractionated heparin or LMWH (or intermediate dose of LMWH), unless there are contraindications, in all non-critically-ill, hospitalized patients [81]. In critically-ill patients, prophylactic doses of unfractionated or LMWH should be considered, whereas intermediate doses of LMWH should be given to high-risk patients [81]. In therapeutic, and not prophylactic settings, administration of LMWH should be considered in hospital, whereas direct oral anticoagulants (DOACs) are recommended after hospital discharge [81]. According to the CHEST guidelines, administration of LMWH or fondaparinux is preferred over unfractionated heparin, in acutely-ill, hospitalized COVID19 patients, in the absence of contraindications, whereas administration of unfractionated heparin is preferred over DOACs [82]. Moreover, in the absence of any contraindications, LMWH is preferred over unfractionated heparin, in critically-ill, COVID-19 patients, whereas administration of LMWH or unfractionated heparin is preferred over fondaparinux or DOACs [82]. The same guidelines recommend administration of standard doses of anticoagulants over intermediate or full-dose treatment, in both acutely-ill or critically-ill COVID-19 patients [82]. Continuation of thromboprophylaxis in COVID-19 patients after hospital discharge is not recommended, unless a net benefit is 
recognized and there is low bleeding risk [82]. Ongoing randomized, controlled trials on antithrombotic therapy in hospitalized COVID-19 patients are summarized in Table 2. These trials will demonstrate the possible clinical usefulness of this therapy in terms of efficacy and safety, not only in the prevention of thrombotic events, but also in the overall clinical management of these patients.

\section{Concluding remarks and future directions}

Patients suffering from respiratory viral infections are at increased risk of manifesting a thrombotic event, of arterial and/or venous origin. However, due to the fact that the available evidence regarding respiratory virus-related thrombotic complications has not been analyzed collectively and in a head-to-head comparison with other viruses, there cannot be a safe conclusion as to whether SARS-CoV-2 is responsible for a worse rate of thrombotic manifestations, compared to other respiratory viruses, or not. These thrombotic events are attributed to various cellular and molecular mechanisms, mainly involving the interplay between a hyperinflammatory response, as well as the activation of platelets and the coagulation cascade. Thus, patients at risk of such events receive antithrombotic drugs either as thromboprophylaxis or as treatment therapy.

In the case of SARS-CoV-2, in addition to current recommendations, ongoing randomized, controlled trials on antithrombotic therapy in hospitalized COVID-19 patients will demonstrate the possible clinical usefulness of this therapy regarding its efficacy and safety, not only in the prevention of thrombotic events, but also in the overall clinical management of these patients.

Author contributions ICM performed the literature search, wrote the draft of the manuscript and approved the final version of the manuscript. ADT conceived the present study, corrected and made additions to the manuscript and approved the final version of the manuscript.

Funding Not applicable.

\section{Compliance with ethical standards}

Conflicts of interest The authors have no conflicts of interest to declare that are relevant to the content of this article.

\section{References}

1. Zheng YY, Ma YT, Zhang JY, Xie X (2020) COVID-19 and the cardiovascular system. Nature reviews Cardiology 17(5):259-260. https://doi.org/10.1038/s41569-020-0360-5
2. Cui J, Li F, Shi ZL (2019) Origin and evolution of pathogenic coronaviruses. Nat Rev Microbiol 17(3):181-192. https://doi. org/10.1038/s41579-018-0118-9

3. Wu F, Zhao S, Yu B, Chen YM, Wang W, Song ZG, Hu Y, Tao ZW, Tian JH, Pei YY, Yuan ML, Zhang YL, Dai FH, Liu Y, Wang QM, Zheng JJ, Xu L, Holmes EC, Zhang YZ (2020) A new coronavirus associated with human respiratory disease in China. Nature 579(7798):265-269. https://doi.org/10.1038/s4158 6-020-2008-3

4. Lu R, Zhao X, Li J, Niu P, Yang B, Wu H, Wang W, Song H, Huang B, Zhu N, Bi Y, Ma X, Zhan F, Wang L, Hu T, Zhou H, Hu Z, Zhou W, Zhao L, Chen J, Meng Y, Wang J, Lin Y, Yuan J, Xie Z, Ma J, Liu WJ, Wang D, Xu W, Holmes EC, Gao GF, Wu G, Chen W, Shi W, Tan W (2020) Genomic characterisation and epidemiology of 2019 novel coronavirus: implications for virus origins and receptor binding. Lancet 395(10224):565-574. https ://doi.org/10.1016/S0140-6736(20)30251-8

5. Wan Y, Shang J, Graham R, Baric RS, Li F (2020) Receptor Recognition by the Novel Coronavirus from Wuhan: an Analysis Based on Decade-Long Structural Studies of SARS Coronavirus. J Virol. https://doi.org/10.1128/JVI.00127-20

6. Bikdeli B, Madhavan MV, Jimenez D, Chuich T, Dreyfus I, Driggin E, Nigoghossian C, Ageno W, Madjid M, Guo Y, Tang LV, Hu Y, Giri J, Cushman M, Quere I, Dimakakos EP, Gibson CM, Lippi G, Favaloro EJ, Fareed J, Caprini JA, Tafur AJ, Burton JR, Francese DP, Wang EY, Falanga A, McLintock C, Hunt BJ, Spyropoulos AC, Barnes GD, Eikelboom JW, Weinberg I, Schulman S, Carrier M, Piazza G, Beckman JA, Steg PG, Stone GW, Rosenkranz S, Goldhaber SZ, Parikh SA, Monreal M, Krumholz HM, Konstantinides SV, Weitz JI, Lip GYH, Global Covid-19 Thrombosis Collaborative Group EbtINE, the Iua SbtESCWGoPC, Right Ventricular F (2020) COVID-19 and Thrombotic or Thromboembolic Disease: Implications for Prevention, Antithrombotic Therapy, and Follow-Up: JACC State-of-the-Art Review. J Am Coll Cardiol 75(23):2950-2973. https://doi.org/10.1016/j. jacc.2020.04.031

7. Bilaloglu S, Aphinyanaphongs Y, Jones S, Iturrate E, Hochman J, Berger JS (2020) Thrombosis in Hospitalized Patients With COVID-19 in a New York City Health System. JAMA 324(8):799-801. https://doi.org/10.1001/jama.2020.13372

8. Kwong JC, Schwartz KL, Campitelli MA, Chung H, Crowcroft NS, Karnauchow T, Katz K, Ko DT, McGeer AJ, McNally D, Richardson DC, Rosella LC, Simor A, Smieja M, Zahariadis G, Gubbay JB (2018) Acute Myocardial Infarction after LaboratoryConfirmed Influenza Infection. The New England journal of medicine 378(4):345-353. https://doi.org/10.1056/NEJMoa1702090

9. Avnon LS, Munteanu D, Smoliakov A, Jotkowitz A, Barski L (2015) Thromboembolic events in patients with severe pandemic influenza $\mathrm{A} / \mathrm{H} 1 \mathrm{~N} 1$. European journal of internal medicine 26(8):596-598. https://doi.org/10.1016/j.ejim.2015.08.017

10. Davidson JA, Warren-Gash C (2019) Cardiovascular complications of acute respiratory infections: current research and future directions. Expert review of anti-infective therapy 17(12):939 942. https://doi.org/10.1080/14787210.2019.1689817

11. Udell JA, Zawi R, Bhatt DL, Keshtkar-Jahromi M, Gaughran F, Phrommintikul A, Ciszewski A, Vakili H, Hoffman EB, Farkouh ME, Cannon CP (2013) Association between influenza vaccination and cardiovascular outcomes in high-risk patients: a metaanalysis. JAMA 310(16):1711-1720. https://doi.org/10.1001/ jama.2013.279206

12. Kreutz RP, Bliden KP, Tantry US, Gurbel PA (2005) Viral respiratory tract infections increase platelet reactivity and activation: an explanation for the higher rates of myocardial infarction and stroke during viral illness. Journal of thrombosis and haemostasis : JTH 3(9):2108-2109. https://doi.org/10.1111/j.1538-7836.2005.01474 .X 
13. Subramaniam S, Scharrer I (2018) Procoagulant activity during viral infections. Frontiers in bioscience 23:1060-1081. https://doi. org/10.2741/4633

14. Hottz ED, Bozza FA, Bozza PT (2018) Platelets in Immune Response to Virus and Immunopathology of Viral Infections. Frontiers in medicine 5:121. https://doi.org/10.3389/ fmed.2018.00121

15. Tsoumani ME, Kalantzi KI, Goudevenos IA, Tselepis AD (2012) Platelet-mediated inflammation in cardiovascular disease Potential role of platelet-endothelium interactions. Curr Vasc Pharmacol 10(5):539-549. https://doi.org/10.2174/157016112801784602

16. Crackower MA, Sarao R, Oudit GY, Yagil C, Kozieradzki I, Scanga SE, Oliveira-dos-Santos AJ, da Costa J, Zhang L, Pei Y, Scholey J, Ferrario CM, Manoukian AS, Chappell MC, Backx PH, Yagil Y, Penninger JM (2002) Angiotensin-converting enzyme 2 is an essential regulator of heart function. Nature 417(6891):822828. https://doi.org/10.1038/nature00786

17. Danilczyk U, Penninger JM (2006) Angiotensin-converting enzyme II in the heart and the kidney. Circ Res 98(4):463-471. https://doi.org/10.1161/01.RES.0000205761.22353.5f

18. Monteil V, Kwon H, Prado P, Hagelkruys A, Wimmer RA, Stahl M, Leopoldi A, Garreta E, Hurtado Del Pozo C, Prosper F, Romero JP, Wirnsberger G, Zhang H, Slutsky AS, Conder R, Montserrat N, Mirazimi A, Penninger JM (2020) Inhibition of SARS-CoV-2 Infections in Engineered Human Tissues Using Clinical-Grade Soluble Human ACE2. Cell 18(4):905-913. https ://doi.org/10.1016/j.cell.2020.04.004

19. Varga Z, Flammer AJ, Steiger P, Haberecker M, Andermatt R, Zinkernagel AS, Mehra MR, Schuepbach RA, Ruschitzka F, Moch $\mathrm{H}$ (2020) Endothelial cell infection and endotheliitis in COVID19. Lancet 395(10234):1417-1418. https://doi.org/10.1016/S0140 $-6736(20) 30937-5$

20. Kayal S, Jais JP, Aguini N, Chaudiere J, Labrousse J (1998) Elevated circulating E-selectin, intercellular adhesion molecule 1 , and von Willebrand factor in patients with severe infection. Am J Respir Crit Care Med 157(3 Pt 1):776-784. https://doi. org/10.1164/ajrccm.157.3.9705034

21. Aird WC (2003) The role of the endothelium in severe sepsis and multiple organ dysfunction syndrome. Blood 101(10):3765-3777. https://doi.org/10.1182/blood-2002-06-1887

22. Massberg S, Enders G, Leiderer R, Eisenmenger S, Vestweber D, Krombach F, Messmer K (1998) Platelet-endothelial cell interactions during ischemia/reperfusion: the role of P-selectin. Blood 92(2):507-515

23. Springer TA (1994) Traffic signals for lymphocyte recirculation and leukocyte emigration: the multistep paradigm. Cell 76(2):301-314. https://doi.org/10.1016/0092-8674(94)90337-9

24. Gupta N, Zhao YY, Evans CE (2019) The stimulation of thrombosis by hypoxia. Thromb Res 181:77-83. https://doi.org/10.1016/j. thromres.2019.07.013

25. McFadyen JD, Stevens H, Peter K (2020) The Emerging Threat of (Micro)Thrombosis in COVID-19 and Its Therapeutic Implications. Circ Res 127(4):571-587. https://doi.org/10.1161/CIRCR ESAHA.120.317447

26. Zhang S, Liu Y, Wang X, Yang L, Li H, Wang Y, Liu M, Zhao X, Xie Y, Yang Y, Zhang S, Fan Z, Dong J, Yuan Z, Ding Z, Zhang Y, Hu L (2020) SARS-CoV-2 binds platelet ACE2 to enhance thrombosis in COVID-19. Journal of hematology \& oncology 13(1):120. https://doi.org/10.1186/s13045-020-00954-7

27. Hu H, Zhu L, Huang Z, Ji Q, Chatterjee M, Zhang W, Li N (2010) Platelets enhance lymphocyte adhesion and infiltration into arterial thrombus. Thromb Haemost 104(6):1184-1192. https://doi. org/10.1160/TH10-05-0308

28. Leon-Ponte M, Ahern GP, O'Connell PJ (2007) Serotonin provides an accessory signal to enhance $\mathrm{T}$-cell activation by signaling through the 5-HT7 receptor. Blood 109(8):3139-3146. https://doi. org/10.1182/blood-2006-10-052787

29. Cognasse F, Hamzeh-Cognasse H, Lafarge S, Chavarin P, Cogne M, Richard Y, Garraud O (2007) Human platelets can activate peripheral blood $\mathrm{B}$ cells and increase production of immunoglobulins. Exp Hematol 35(9):1376-1387. https://doi.org/10.1016/j. exphem.2007.05.021

30. Brinkmann V, Reichard U, Goosmann C, Fauler B, Uhlemann Y, Weiss DS, Weinrauch Y, Zychlinsky A (2004) Neutrophil extracellular traps kill bacteria. Science 303(5663):1532-1535. https ://doi.org/10.1126/science.1092385

31. Moschonas IC, Tselepis AD (2019) The pathway of neutrophil extracellular traps towards atherosclerosis and thrombosis. Atherosclerosis 288:9-16. https://doi.org/10.1016/j.atherosclerosis .2019.06.919

32. Saffarzadeh M, Juenemann C, Queisser MA, Lochnit G, Barreto G, Galuska SP, Lohmeyer J, Preissner KT (2012) Neutrophil extracellular traps directly induce epithelial and endothelial cell death: a predominant role of histones. PLoS ONE 7(2):e32366. https://doi.org/10.1371/journal.pone.0032366

33. Allen C, Thornton P, Denes A, McColl BW, Pierozynski A, Monestier M, Pinteaux E, Rothwell NJ, Allan SM (2012) Neutrophil cerebrovascular transmigration triggers rapid neurotoxicity through release of proteases associated with decondensed DNA. Journal of immunology 189(1):381-392. https://doi.org/10.4049/ jimmunol.1200409

34. Schonrich G, Raftery MJ (2016) Neutrophil Extracellular Traps Go Viral. Frontiers in immunology 7:366. https://doi.org/10.3389/ fimmu.2016.00366

35. Narasaraju T, Tang BM, Herrmann M, Muller S, Chow VTK, Radic M (2020) Neutrophilia and NETopathy as Key Pathologic Drivers of Progressive Lung Impairment in Patients With COVID19. Frontiers in pharmacology 11:870. https://doi.org/10.3389/ fphar.2020.00870

36. Tomar B, Anders HJ, Desai J, Mulay SR (2020) Neutrophils and Neutrophil Extracellular Traps Drive Necroinflammation in COVID-19. Cells. https://doi.org/10.3390/cells9061383

37. Zuo Y, Yalavarthi S, Shi H, Gockman K, Zuo M, Madison JA, Blair CN, Weber A, Barnes BJ, Egeblad M, Woods RJ, Kanthi Y, Knight JS (2020) Neutrophil extracellular traps in COVID-19. JCI insight. https://doi.org/10.1172/jci.insight.138999

38. Barnes BJ, Adrover JM, Baxter-Stoltzfus A, Borczuk A, CoolsLartigue J, Crawford JM, Dassler-Plenker J, Guerci P, Huynh C, Knight JS, Loda M, Looney MR, McAllister F, Rayes R, Renaud S, Rousseau S, Salvatore S, Schwartz RE, Spicer JD, Yost CC, Weber A, Zuo Y, Egeblad M (2020) Targeting potential drivers of COVID-19: Neutrophil extracellular traps. J Exp Med. https:// doi.org/10.1084/jem.20200652

39. Maugeri N, Campana L, Gavina M, Covino C, De Metrio M, Panciroli C, Maiuri L, Maseri A, D’Angelo A, Bianchi ME, Rovere-Querini P, Manfredi AA (2014) Activated platelets present high mobility group box 1 to neutrophils, inducing autophagy and promoting the extrusion of neutrophil extracellular traps. Journal of thrombosis and haemostasis : JTH 12(12):2074-2088. https:// doi.org/10.1111/jth. 12710

40. Stakos DA, Kambas K, Konstantinidis T, Mitroulis I, Apostolidou E, Arelaki S, Tsironidou V, Giatromanolaki A, Skendros P, Konstantinides S, Ritis K (2015) Expression of functional tissue factor by neutrophil extracellular traps in culprit artery of acute myocardial infarction. Eur Heart J 36(22):1405-1414. https://doi. org/10.1093/eurheartj/ehv007

41. Carestia A, Kaufman T, Rivadeneyra L, Landoni VI, Pozner RG, Negrotto S, D'Atri LP, Gomez RM, Schattner M (2016) Mediators and molecular pathways involved in the regulation of neutrophil extracellular trap formation mediated by activated platelets. J Leukoc Biol 99(1):153-162. https://doi.org/10.1189/jlb.3A0415-161R 
42. Clark SR, Ma AC, Tavener SA, McDonald B, Goodarzi Z, Kelly MM, Patel KD, Chakrabarti S, McAvoy E, Sinclair GD, Keys EM, Allen-Vercoe E, Devinney R, Doig CJ, Green FH, Kubes P (2007) Platelet TLR4 activates neutrophil extracellular traps to ensnare bacteria in septic blood. Nat Med 13(4):463-469. https ://doi.org/10.1038/nm1565

43. Fuchs TA, Brill A, Duerschmied D, Schatzberg D, Monestier M, Myers DD Jr, Wrobleski SK, Wakefield TW, Hartwig JH, Wagner DD (2010) Extracellular DNA traps promote thrombosis. Proc Natl Acad Sci USA 107(36):15880-15885. https://doi. org/10.1073/pnas.1005743107

44. Elaskalani O, Abdol Razak NB, Metharom P (2018) Neutrophil extracellular traps induce aggregation of washed human platelets independently of extracellular DNA and histones. Cell communication and signaling : CCS 16(1):24. https://doi.org/10.1186/ s12964-018-0235-0

45. Reyes-Garcia AML, Aroca A, Arroyo AB, Garcia-Barbera N, Vicente V, Gonzalez-Conejero R, Martinez C (2019) Neutrophil extracellular trap components increase the expression of coagulation factors. Biomedical reports 10(3):195-201. https://doi. org/10.3892/br.2019.1187

46. Berlin DA, Gulick RM, Martinez FJ (2020) Severe Covid-19. The New England journal of medicine. https://doi.org/10.1056/NEJMc p2009575

47. Jose RJ, Manuel A (2020) COVID-19 cytokine storm: the interplay between inflammation and coagulation. The Lancet Respiratory medicine 8(6):e46-e47. https://doi.org/10.1016/S2213 -2600(20)30216-2

48. Mehta P, McAuley DF, Brown M, Sanchez E, Tattersall RS, Manson JJ, Collaboration HAS, UK, (2020) COVID-19: consider cytokine storm syndromes and immunosuppression. Lancet 395(10229):1033-1034. https://doi.org/10.1016/S0140 -6736(20)30628-0

49. Maglakelidze N, Manto KM, Craig TJ (2020) A Review: Does Complement or the Contact System Have a Role in Protection or Pathogenesis of COVID-19? Pulmonary therapy. https://doi. org/10.1007/s41030-020-00118-5

50. Moschonas IC, Goudevenos JA, Tselepis AD (2015) Proteaseactivated receptor-1 antagonists in long-term antiplatelet therapy. Current state of evidence and future perspectives. Int J Cardiol 185:9-18. https://doi.org/10.1016/j.ijcard.2015.03.049

51. Mendoza-Pinto C, Escarcega RO, Garcia-Carrasco M, Bailey DJO, Galvez-Romero JL, Cervera R (2020) Viral Infections and Their Relationship with Catastrophic Antiphospholipid Syndrome: A Possible Pathogenic Mechanism of Severe COVID-19 Thrombotic Complications. J Intern Med. https://doi.org/10.1111/ joim. 13123

52. Zhang Y, Xiao M, Zhang S, Xia P, Cao W, Jiang W, Chen H, Ding $\mathrm{X}$, Zhao H, Zhang H, Wang C, Zhao J, Sun X, Tian R, Wu W, Wu D, Ma J, Chen Y, Zhang D, Xie J, Yan X, Zhou X, Liu Z, Wang J, Du B, Qin Y, Gao P, Qin X, Xu Y, Zhang W, Li T, Zhang F, Zhao Y, Li Y, Zhang S (2020) Coagulopathy and Antiphospholipid Antibodies in Patients with Covid-19. The New England journal of medicine 382(17):e38. https://doi.org/10.1056/NEJMc2007575

53. Borghi MO, Beltagy A, Garrafa E, Curreli D, Cecchini G, Bodio C, Grossi C, Blengino S, Tincani A, Franceschini F, Andreoli L, Lazzaroni MG, Piantoni S, Masneri S, Crisafulli F, Brugnoni D, Muiesan ML, Salvetti M, Parati G, Torresani E, Mahler M, Heilbron F, Pregnolato F, Pengo M, Tedesco F, Pozzi N, Meroni PL (2020) Prevalence, specificity, and clinical association of antiphospholipid antibodies in COVID-19 patients are the antibodies really guilty? medRxiv. The preprint server for health sciences. https://doi.org/10.1101/2020.06.17.20134114

54. Zuo Y, Estes SK, Gandhi AA, Yalavarthi S, Ali RA, Shi H, Sule G, Gockman K, Madison JA, Zuo M, Woodard W, Lezak SP, Lugogo NL, Kanthi Y, Knight JS (2020) Prothrombotic antiphospholipid antibodies in COVID-19 medRxiv. The preprint server for health sciences. https://doi.org/10.1101/2020.06.15.20131607

55. Wirestam L, Arve S, Linge P, Bengtsson AA (2019) NeutrophilsImportant Communicators in Systemic Lupus Erythematosus and Antiphospholipid Syndrome. Frontiers in immunology 10:2734. https://doi.org/10.3389/fimmu.2019.02734

56. Tang N, Li D, Wang X, Sun Z (2020) Abnormal coagulation parameters are associated with poor prognosis in patients with novel coronavirus pneumonia. Journal of thrombosis and haemostasis : JTH 18(4):844-847. https://doi.org/10.1111/jth.14768

57. Cui S, Chen S, Li X, Liu S, Wang F (2020) Prevalence of venous thromboembolism in patients with severe novel coronavirus pneumonia. J Thromb Haemost. https://doi.org/10.1111/jth.14830

58. Klok FA, Kruip M, van der Meer NJM, Arbous MS, Gommers D, Kant KM, Kaptein FHJ, van Paassen J, Stals MAM, Huisman MV, Endeman H (2020) Incidence of thrombotic complications in critically ill ICU patients with COVID-19. Thromb Res. https ://doi.org/10.1016/j.thromres.2020.04.013

59. Faggiano P, Bonelli A, Paris S, Milesi G, Bisegna S, Bernardi N, Curnis A, Agricola E, Maroldi R (2020) Acute pulmonary embolism in COVID-19 disease: Preliminary report on seven patients. Int J Cardiol. https://doi.org/10.1016/j.ijcard.2020.04.028

60. Bunce PE, High SM, Nadjafi M, Stanley K, Liles WC, Christian MD (2011) Pandemic H1N1 influenza infection and vascular thrombosis. Clinical infectious diseases : an official publication of the Infectious Diseases Society of America 52(2):e14-17. https ://doi.org/10.1093/cid/ciq125

61. Warren-Gash C, Hayward AC, Hemingway H, Denaxas S, Thomas SL, Timmis AD, Whitaker H, Smeeth L (2012) Influenza infection and risk of acute myocardial infarction in England and Wales: a CALIBER self-controlled case series study. J Infect Dis 206(11):1652-1659. https://doi.org/10.1093/infdis/jis597

62. Obi AT, Tignanelli CJ, Jacobs BN, Arya S, Park PK, Wakefield TW, Henke PK, Napolitano LM (2019) Empirical systemic anticoagulation is associated with decreased venous thromboembolism in critically ill influenza A H1N1 acute respiratory distress syndrome patients. Journal of vascular surgery Venous and lymphatic disorders 7(3):317-324. https://doi.org/10.1016/j. jvsv.2018.08.010

63. Giannis D, Ziogas IA, Gianni P (2020) Coagulation disorders in coronavirus infected patients: COVID-19, SARS-CoV-1, MERS$\mathrm{CoV}$ and lessons from the past. Journal of clinical virology : the official publication of the Pan American Society for Clinical Virology 127:104362. https://doi.org/10.1016/j.jcv.2020.104362

64. Shahjouei S, Naderi S, Li J, Khan A, Chaudhary D, Farahmand G, Male S, Griessenauer C, Sabra M, Mondello S, Cernigliaro A, Khodadadi F, Dev A, Goyal N, Ranji-Burachaloo S, Olulana O, Avula V, Ebrahimzadeh SA, Alizada O, Hanci MM, Ghorbani A, Vaghefi Far A, Ranta A, Punter M, Ramezani M, Ostadrahimi N, Tsivgoulis G, Fragkou PC, Nowrouzi-Sohrabi P, Karofylakis E, Tsiodras S, Neshin Aghayari Sheikh S, Saberi A, Niemela M, Rezai Jahromi B, Mowla A, Mashayekhi M, Bavarsad Shahripour R, Sajedi SA, Ghorbani M, Kia A, Rahimian N, Abedi V, Zand $\mathrm{R}$ (2020) Risk of stroke in hospitalized SARS-CoV-2 infected patients: A multinational study. EBioMedicine 59:102939. https ://doi.org/10.1016/j.ebiom.2020.102939

65. Sridharan GK, Vegunta R, Rokkam VRP, Meyyur Aravamudan V, Vegunta R, Khan SR, Ponnada S, Boregowda U, Prudhvi K, Chamarthi G, Mohan BP (2020) Venous Thromboembolism in Hospitalized COVID-19 Patients. Am J Ther 27(6):e599-e610. https://doi.org/10.1097/MJT.0000000000001295

66. Lee N, Hui D, Wu A, Chan P, Cameron P, Joynt GM, Ahuja A, Yung MY, Leung CB, To KF, Lui SF, Szeto CC, Chung S, Sung JJ (2003) A major outbreak of severe acute respiratory syndrome in Hong Kong. The New England journal of medicine 348(20):1986-1994. https://doi.org/10.1056/NEJMoă85 
67. Ding Y, Wang H, Shen H, Li Z, Geng J, Han H, Cai J, Li X, Kang W, Weng D, Lu Y, Wu D, He L, Yao K (2003) The clinical pathology of severe acute respiratory syndrome (SARS): a report from China. J Pathol 200(3):282-289. https://doi.org/10.1002/ path. 1440

68. Nicholls JM, Poon LL, Lee KC, Ng WF, Lai ST, Leung CY, Chu CM, Hui PK, Mak KL, Lim W, Yan KW, Chan KH, Tsang NC, Guan Y, Yuen KY, Peiris JS (2003) Lung pathology of fatal severe acute respiratory syndrome. Lancet 361(9371):1773-1778. https ://doi.org/10.1016/s0140-6736(03)13413-7

69. Yang M, Hon KL, Li K, Fok TF, Li CK (2003) The effect of SARS coronavirus on blood system: its clinical findings and the pathophysiologic hypothesis. Zhongguo shi yan xue ye xue za zhi 11(3):217-221

70. Wong RS, Wu A, To KF, Lee N, Lam CW, Wong CK, Chan PK, Ng MH, Yu LM, Hui DS, Tam JS, Cheng G, Sung JJ (2003) Haematological manifestations in patients with severe acute respiratory syndrome: retrospective analysis. BMJ 326(7403):13581362. https://doi.org/10.1136/bmj.326.7403.1358

71. Umapathi T, Kor AC, Venketasubramanian N, Lim CC, Pang BC, Yeo TT, Lee CC, Lim PL, Ponnudurai K, Chuah KL, Tan PH, Tai DY, Ang SP (2004) Large artery ischaemic stroke in severe acute respiratory syndrome (SARS). J Neurol 251(10):1227-1231. https ://doi.org/10.1007/s00415-004-0519-8

72. Assiri A, Al-Tawfiq JA, Al-Rabeeah AA, Al-Rabiah FA, AlHajjar S, Al-Barrak A, Flemban H, Al-Nassir WN, Balkhy HH, Al-Hakeem RF, Makhdoom HQ, Zumla AI, Memish ZA (2013) Epidemiological, demographic, and clinical characteristics of 47 cases of Middle East respiratory syndrome coronavirus disease from Saudi Arabia: a descriptive study. Lancet Infect Dis 13(9):752-761. https://doi.org/10.1016/S1473-3099(13)70204-4

73. Hwang SM, Na BJ, Jung Y, Lim HS, Seo JE, Park SA, Cho YS, Song EH, Seo JY, Kim SR, Lee GY, Kim SJ, Park YS, Seo H (2019) Clinical and Laboratory Findings of Middle East Respiratory Syndrome Coronavirus Infection. Japanese journal of infectious diseases 72(3):160-167. https://doi.org/10.7883/yoken .JJID.2018.187

74. Al-Abdallat MM, Payne DC, Alqasrawi S, Rha B, Tohme RA, Abedi GR, Al Nsour M, Iblan I, Jarour N, Farag NH, Haddadin A, Al-Sanouri T, Tamin A, Harcourt JL, Kuhar DT, Swerdlow DL, Erdman DD, Pallansch MA, Haynes LM, Gerber SI, Jordan M-CIT (2014) Hospital-associated outbreak of Middle East respiratory syndrome coronavirus: a serologic, epidemiologic, and clinical description. Clinical infectious diseases : an official publication of the Infectious Diseases Society of America 59(9):12251233. https://doi.org/10.1093/cid/ciu359

75. Algahtani H, Subahi A, Shirah B (2016) Neurological Complications of Middle East Respiratory Syndrome Coronavirus:
A Report of Two Cases and Review of the Literature. Case reports in neurological medicine 2016:3502683. https://doi. org/10.1155/2016/3502683

76. Singh SK (2016) Middle East Respiratory Syndrome Virus Pathogenesis. Seminars in respiratory and critical care medicine 37(4):572-577. https://doi.org/10.1055/s-0036-1584796

77. Artifoni M, Danic G, Gautier G, Gicquel P, Boutoille D, Raffi F, Neel A, Lecomte R (2020) Systematic assessment of venous thromboembolism in COVID-19 patients receiving thromboprophylaxis: incidence and role of D-dimer as predictive factors. J Thromb Thrombolysis. https://doi.org/10.1007/s11239-020-02146 $-\mathrm{Z}$

78. Llitjos JF, Leclerc M, Chochois C, Monsallier JM, Ramakers M, Auvray M, Merouani K (2020) High incidence of venous thromboembolic events in anticoagulated severe COVID-19 patients. Journal of thrombosis and haemostasis : JTH. doi:https://doi. org/10.1111/jth. 14869

79. Tang N, Bai H, Chen X, Gong J, Li D, Sun Z (2020) Anticoagulant treatment is associated with decreased mortality in severe coronavirus disease 2019 patients with coagulopathy. Journal of thrombosis and haemostasis : JTH 18(5):1094-1099. https://doi. org/10.1111/jth.14817

80. Thachil J, Tang N, Gando S, Falanga A, Cattaneo M, Levi M, Clark C, Iba T (2020) ISTH interim guidance on recognition and management of coagulopathy in COVID-19. Journal of thrombosis and haemostasis : JTH 18(5):1023-1026. https://doi. org/10.1111/jth. 14810

81. Spyropoulos AC, Levy JH, Ageno W, Connors JM, Hunt BJ, Iba T, Levi M, Samama CM, Thachil J, Giannis D, Douketis JD, Subcommittee on Perioperative CCTHotSSCotISoTH (2020) Scientific and Standardization Committee Communication: Clinical Guidance on the Diagnosis, Prevention and Treatment of Venous Thromboembolism in Hospitalized Patients with COVID-19. Journal of thrombosis and haemostasis : JTH. doi:https://doi. org/10.1111/jth.14929

82. Moores LK, Tritschler T, Brosnahan S, Carrier M, Collen JF, Doerschug K, Holley AB, Jimenez D, LeGal G, Rali P, Wells P (2020) Prevention, diagnosis and treatment of venous thromboembolism in patients with COVID-19: CHEST Guideline and Expert Panel Report. Chest. https://doi.org/10.1016/j.chest.2020.05.559

Publisher's Note Springer Nature remains neutral with regard to jurisdictional claims in published maps and institutional affiliations. 